\title{
SUPREME EDICTS OF EMPRESS EKATERINA II ON THE EXISTING CATHOLIC CHURCHES IN RUSSIA
}

\author{
YULIA POLIAKOVA (DEVONISSKAYA - PISTOLYAKA) ${ }^{1}$
}

Federico Santa María Technical University, Valparaíso, Chile

\begin{abstract}
Legal history researchers are offered the translation of the set of 10 original Old Russian texts from the s. XVIII, entitled SUPREME EDICTS OF EMPRESS EKATERINA II ON THE EXISTING CATHOLIC CHURCHES IN RUSSIA, Regulatory Acts of the Orthodox State regarding the permits granted to the Catholic Church, with comments from the translator. The work is composed of the Regulations of the Roman Catholic Church of Saint Petersburg and others that exist in Russia by Ekaterina II of February 12, 1769, and the Decrees (1772-1782) relative the Christian churches of the Creeds: Orthodox, Roman Catholic and Greek Catholic (Uniate) in the territory of Belarus, recently annexed from Poland.
\end{abstract}

\section{KEYWORDS}

Supreme Edicts, Empress Ekaterina II (Catherine II the Great), Belarus, Christian churches of the Creeds: Orthodox, Roman Catholic and Greek Catholic (Uniate).

\footnotetext{
${ }^{1}$ Master of Physics, Moscow State University Lomonosov, Russia. Master of history from the University of Valparaiso, Chile. Professor at the Technical University Federico Santa Maria, Valparaiso, Chile. Postal address: Avenida España 1680, Valparaiso, Chile, Universidad Técnica Federico Santa Maria, mail: yulia.poliakova@usm.cl
} 


\section{NTRODUCTION}

In the eighteenth-century European world, intolerant of the creeds of others, Ekaterina II expresses the contemporary vision of respect and tolerance for the religion of foreign residents and new subjects incorporated into her Empire in 1772, after the division of Poland.

Our work consists in the complete translation of the reissue of a bilingual Russian-Latin set of ten regulatory acts of Empress Ekaterina II (Catherine the Great of Russia), of which only two are published in Legislation of Ekaterina $I^{2}$, while the others eight are in the National Archives. We respect the form of government writings and the style of the Empress. We believe that this contribution makes documents that are difficult to access, especially without knowledge of the Russian language, available to researchers We are not aware of publications to date on the aforementioned set of Supreme Edicts either outside or within Russia $^{3}$. The comments also give brief information on the content of each document.

Originally, this collection of documents was an intimate literary gift from the author of the Latin translation of the SUPREME EDICTS ON THE EXISTING CATHOLIC CHURCHES IN RUSSIA ${ }^{4}$, Dr Philipp Heinrich Dilthey (1723-1781) ${ }^{5}$, with his cordial dedication to the prominent prelate Stanislav Sestrentsevich, the first Catholic Bishop and then Archbishop of the Empire. This intellectual present was a small book 12x13.5 centimeters in size, with elegant Latin characters. We do not know when or where it was published, but we do know that the last document of its translation dates from January 2, 1780, because Dilthey died after a long illness November 12, 1781.

After the year 1782, the subsequent three Latin documents were printed (undated) in the archepiscopal Mogilev typeface included in the reissue, presumably by order of Archbishop Sestrentsevich. The last two were of great importance for the Catholic Church, for the Reverend Father and the Society of Jesus. Sestrentsevich made public the set of documents among those sent directly to him and the others where his name is mentioned - for ecclesiastics and Catholic seminarians of Russia, sending them to all clerical institutions.

\footnotetext{
${ }^{2}$ CHISTYAKOV, O. I., NOVITSKAYA, T. E. Legislation of Ekaterina II, (Moscow, Ed. Legal Literature, 2000).

${ }^{3}$ There is an extensive bibliography of the religious policy of Ekaterina II in domestic and foreign sources. We recommend the bibliography occupied by us in our research on this topic at the end of the work.

${ }^{4}$ Supreme edicts are the UKAZ in Russian, signed by The Empress.

${ }^{5}$ Dr. Dilthey Philip Heinrich (1723-1781), the first and for ten years only professor of Law at the Imperial University of Moscow. Dr. of natural Law, Roman, feudal Law and Public Law. He offered students courses in Latin, German, French and Italian. Professor of universal History. Author of six fundamental books.
} 
We do not know when and who's idea was to reissue the bilingual Russian-Latin set that appeared in the Moscow State Historical Library. In 1996 I found in the high demand room three copies already deteriorated, while in 1999 there was only one left, combined with the sheets in better condition of the 3 copies. I was lucky in persuading the library administration to authorize me to make a scanned copy of it, to deliver the Spanish translation to interested researchers in the Latin world.

The reader can appreciate the status of the latest reissue in the image below.

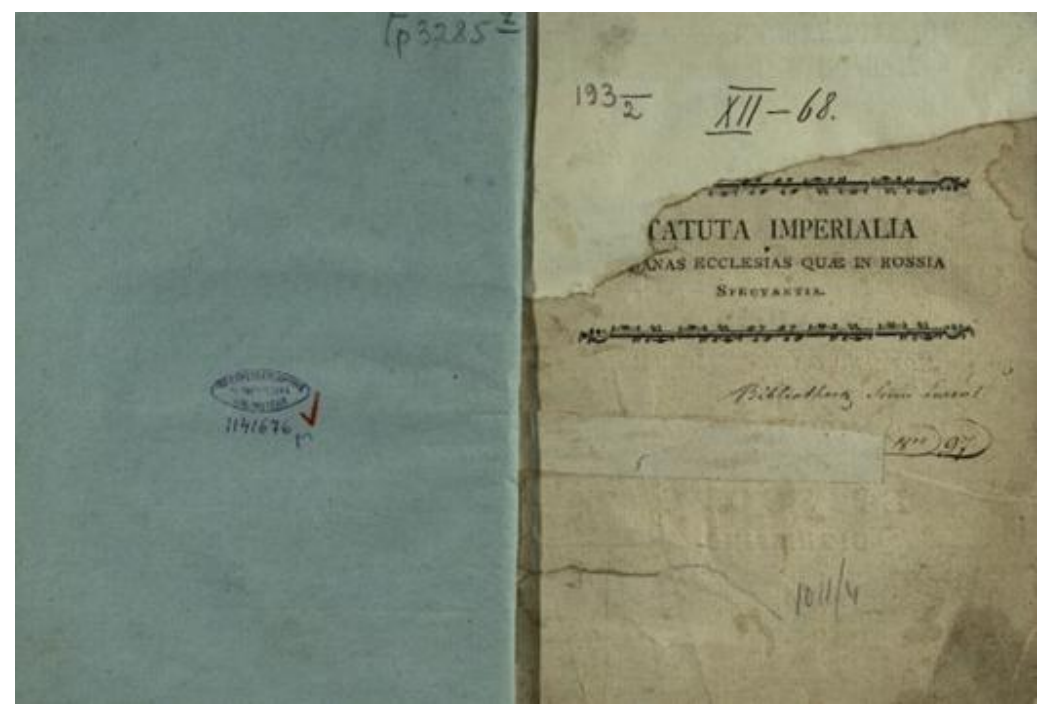

\section{OUR COMMENTS ON THE DOCUMENTS.}

\section{DOCUMENT \# 1}

\section{REGULATION OF THE ROMAN CATHOLIC CHURCH OF SAINT PETERSBURG} AND OTHERS THAT EXIST IN RUSSIA BY EKATERINA II. ON FEBRUARY 12, 1769.

This is the fundamental legal document prepared by the Empress following a complaint from the multinational ${ }^{6}$ Catholic community of foreign residents of Saint Petersburg, about the conduct of the Roman Curia for not meeting the requests of the faithful, and not stopping the financial abuse of the hired priests. Ekaterina legislates on the operation of the Church in favor of the parishioners without touching religious matters. Among the main items is the condition for hired clergy to know the languages of the faithful. Control of the assets by the community is handed over to the committee of trustees, democratically elected among

\footnotetext{
${ }^{6}$ The Catholic community in Saint Petersburg was made up of Poles, French, Germans, and Italians.
} 
themselves by the parishioners, which avoids their unilateral management by the parish priest. Communication with Rome is allowed only for spiritual matters. The direct intervention of the Empress helped the faithful to save the money of the personal interests of the priests sent from Rome and thus finish, successfully, the construction of the church. On February 12, 1769, the Regulation for the Church of Saint Ekaterina of Alexandria in Saint Petersburg was published, which as an Imperial Law was given to both the clergy and the parishioners, to regularize the economic functioning of the parish and achieve preaching understandable to all customers. The rules of the Regulation were transferred to the Moscow church and then to the German peasant colonies of the Volga basin. The Regulation produced great discrepancies with Rome for many years.

Ekaterina denied the right of the Roman Curia to appoint priests and control the property of Catholics in Russia. The Holy See did not recognize the legitimacy of the Regulation because, among other reasons, it undermined the authority of Rome, inviting the participation of parishioners to take responsibility for the business of the community. Despite attempts to force the Empress to ease the measures, the Regulations of 1769 were applied in practice and survived until the concordat established between Russia and Rome in 1847.

Said document from the bilingual set was partially lost as the old paper deteriorated. We resort to its publication in the work Legislation of Ekaterina $I I^{7}$. The complete analysis of the document and its translation was published in $R E H J^{8}$.

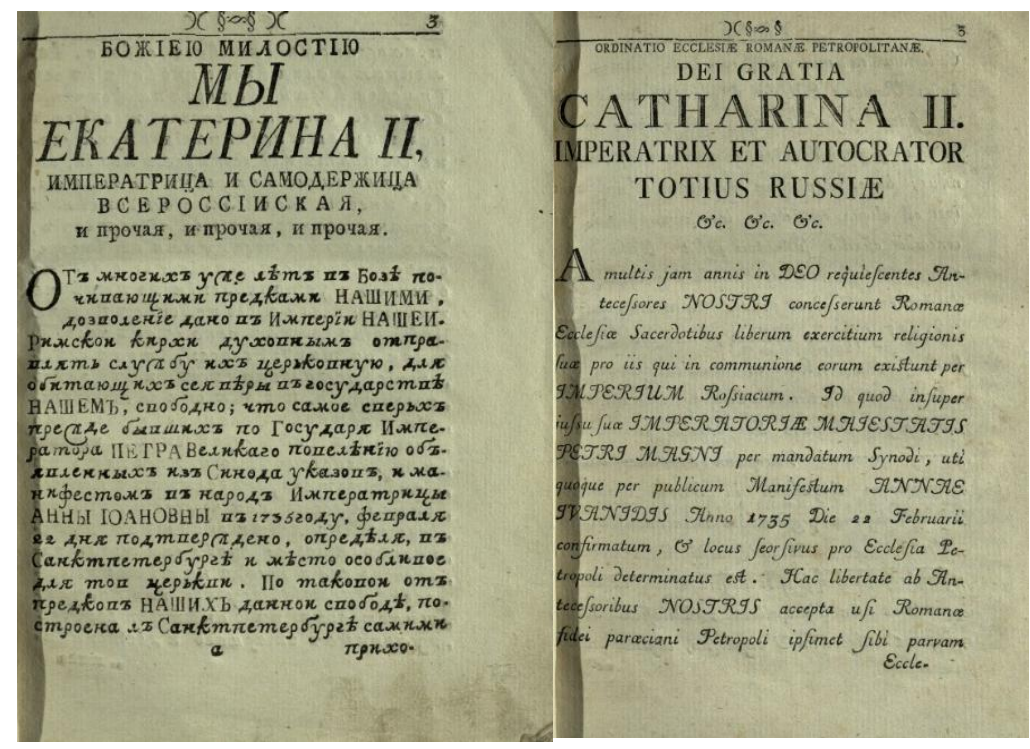

\footnotetext{
${ }^{7}$ CHISTYAKOV, O.I., NOVITSKAYA, T. E. cit. (n1) I. Ch.3.2 On non-orthodox religions, doc.148. pp. 997 sqq.

${ }^{8}$ REHJ. XXXIX (2017), pp. 385-402.
} 
The first pages of document \# 1 in Russian and Latin of the reissue ${ }^{9}$.

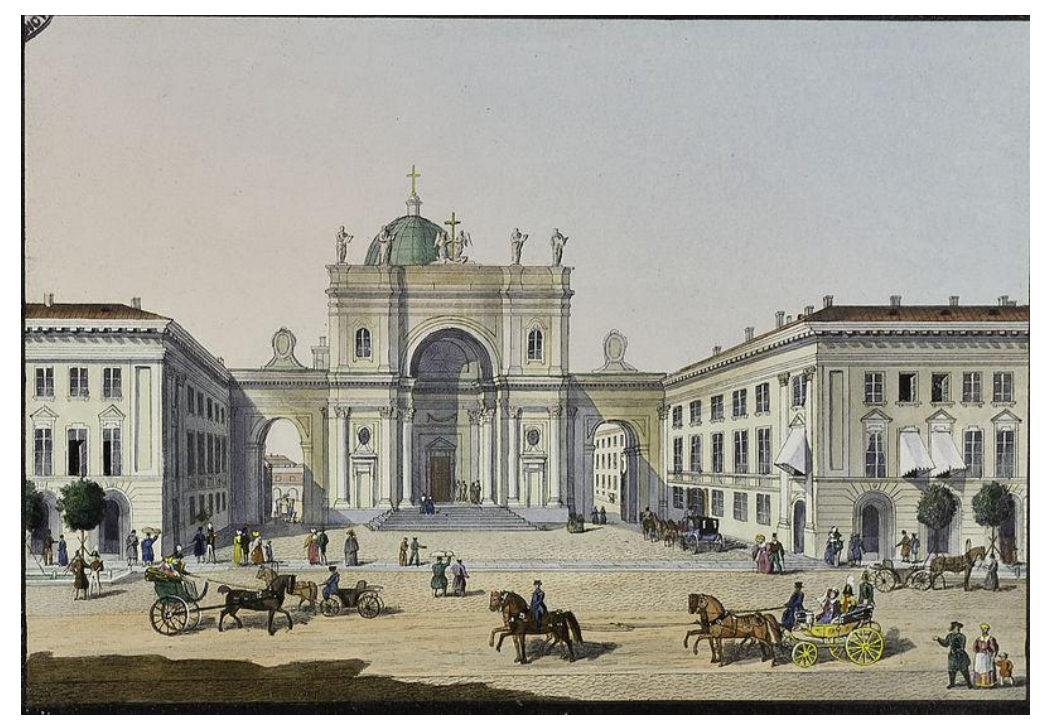

Saint Petersburg at the beginning of the 19th century. Saint Ekaterina of Alexandria Catholic Church $^{10}$

\section{DOCUMENT \# 2}

ORDER TO OUR SENATE ON THE JURISDICTION OF THE CHURCHES FOR BOTH OUR ORTHODOX CONFESSION, AS WELL AS FOR ROMAN AND UNIATE GREEKROMAN CATHOLIC INSTITUTIONS IN NEW TERRITORIES OF WHITE RUSSIA ${ }^{11}$, RECENTLY ACQUIRED FROM POLAND TO THE RUSSIAN EMPIRE. ON DECEMBER 14, 1772.

After the first partition of Poland ${ }^{12}$ between Prussia, Russia, and Austria, formalized August 5, 1772, Russia regained its former lands ${ }^{13}$ making them the governorates of Pskov and Mogilev. The total area reintegrated into the empire comprised $93,000 \mathrm{~km} 2$, with a population of 1,300,000 people, of which about 100,000 were Roman Catholics and 800,000

\footnotetext{
${ }^{9}$ Moscow State Historical Library.

${ }^{10}$ Lithograph by Karl Beggrov (1799-1875), member of the Saint Petersburg Academy of Fine Arts. Municipal Library of Nancy. France http://www.flickr.com/photos/bmnstanislas/10741912194/ Visited 06.04.2018.

${ }^{11}$ Belarus.

${ }^{12}$ Commonwealth of the Kingdom of Poland and Grand Duchy of Lithuania existed since 1569, governed by Polish kings elected by the legislative chamber (Sejm) controlled by the nobility (Szlachta in Polish), with power limited by laws.

${ }^{13}$ The territories of Kievan Rus incorporated in the 14th century to the Grand Duchy of Lithuania which was part of the Commonwealth with Poland in the 16th century.
} 
Greek Rite Catholics, the Uniates. That is, about 900 thousand Catholics of both rites came under the domain of the non-Catholic sovereign. The population - in its ethnic composition was mainly of Russian origin, but it was recognized as Polish. The orthodox faith that formerly dominated there was strongly weakened by the Roman and the Uniate. There were around 30 Catholic religious orders (male and female), where the most influential and wealthy was the Society of Jesus. Ekaterina declares about the assignment of the spiritual direction of the Orthodox to the ecclesiastical hierarchs assigned ${ }^{14}$ to two new provinces. To the Roman Catholic Bishop (still vacant), the direction of churches and convents in Belarus and of churches in Russia with the power to ordain a new Roman clergy is given, replacing the one hired in Rome; and Archbishop Uniate are commissioned churches and convents only in newly obtained provinces.

This document was lost from the bilingual set (minus the last pages) due to deterioration of the old paper. We resort to its publication in Legislation of Ekaterina $I^{15}$.

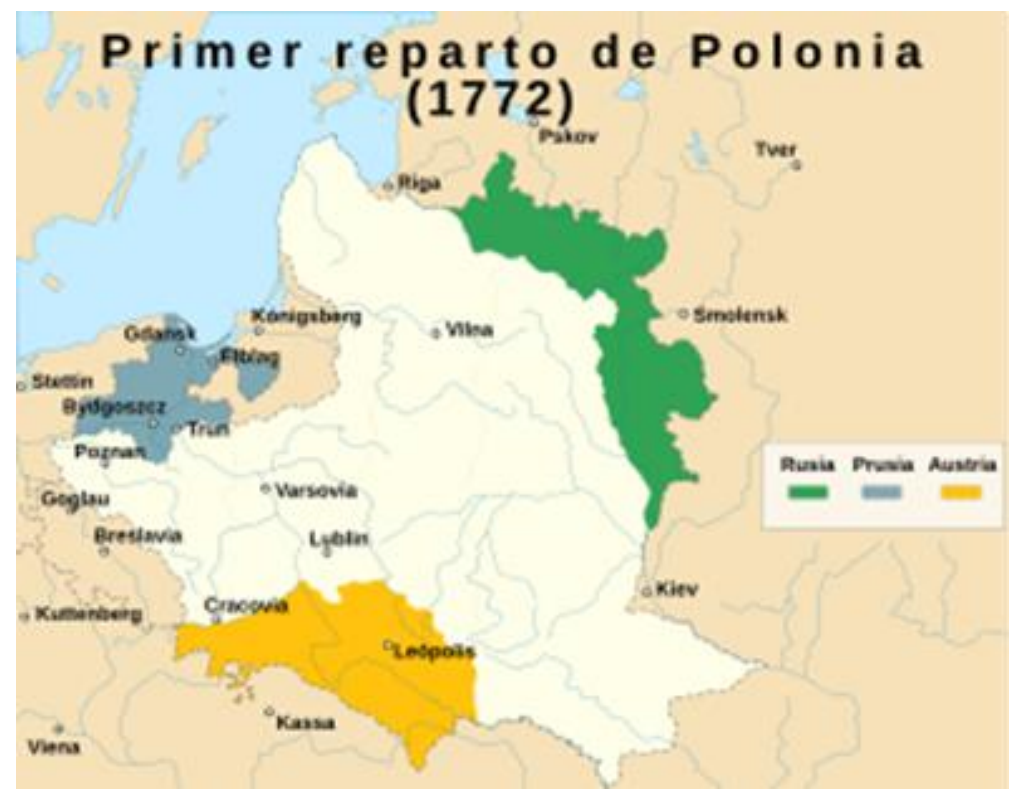

Map of the first partition of Poland in $1772^{16}$

\footnotetext{
${ }^{14}$ The Holy Synod, the supreme Russian ecclesiastical authority, assigned the Orthodox hierarchs with the imperial confirmation.

${ }^{15}$ Op. cit. (n1) doc. 149. pp. $1006 \mathrm{~s}$.

${ }^{16} \underline{\text { https://es.wikipedia.org/wiki/Primera_partici\% } \% \text { C3\%B3n_de_Polonia }}$
} 


\section{DOCUMENT \# 3}

\section{MANDATE TO OUR SUPREME GENERAL AND GENERAL GOVERNOR OF BELARUS COUNT CHERNISHOV ON THE APPOINTMENT OF STANISLAV SESTRENTSEVICH AS BISHOP OF BELARUS. ON NOVEMBER 22, 1773.}

Stanislav Sestrentsevich was chosen by the Empress to lead the native Catholics of Belarus and residents of the country, giving him his trust as he learned that he was the only priest in Poland who condemned as a great sin an attempt by members of the Confederacy of $\operatorname{Bar}^{17}$ for killing the king. She was concerned that her bishop's financial situation was excellent and comfortable to fulfil the tasks set forth. Sestrentsevich united the remains of nine Catholic dioceses, which remained in Belarus after the first partition of Poland in 1772. He also put together a solid institution with restored churches, a seminary, and the priestly training system. Dr Philipp Heinrich Dilthey left in his written legacy a cordial dedication to Reverend Sestrentsevich, acknowledging his tireless pastoral work for the entire Catholic community in Russia.

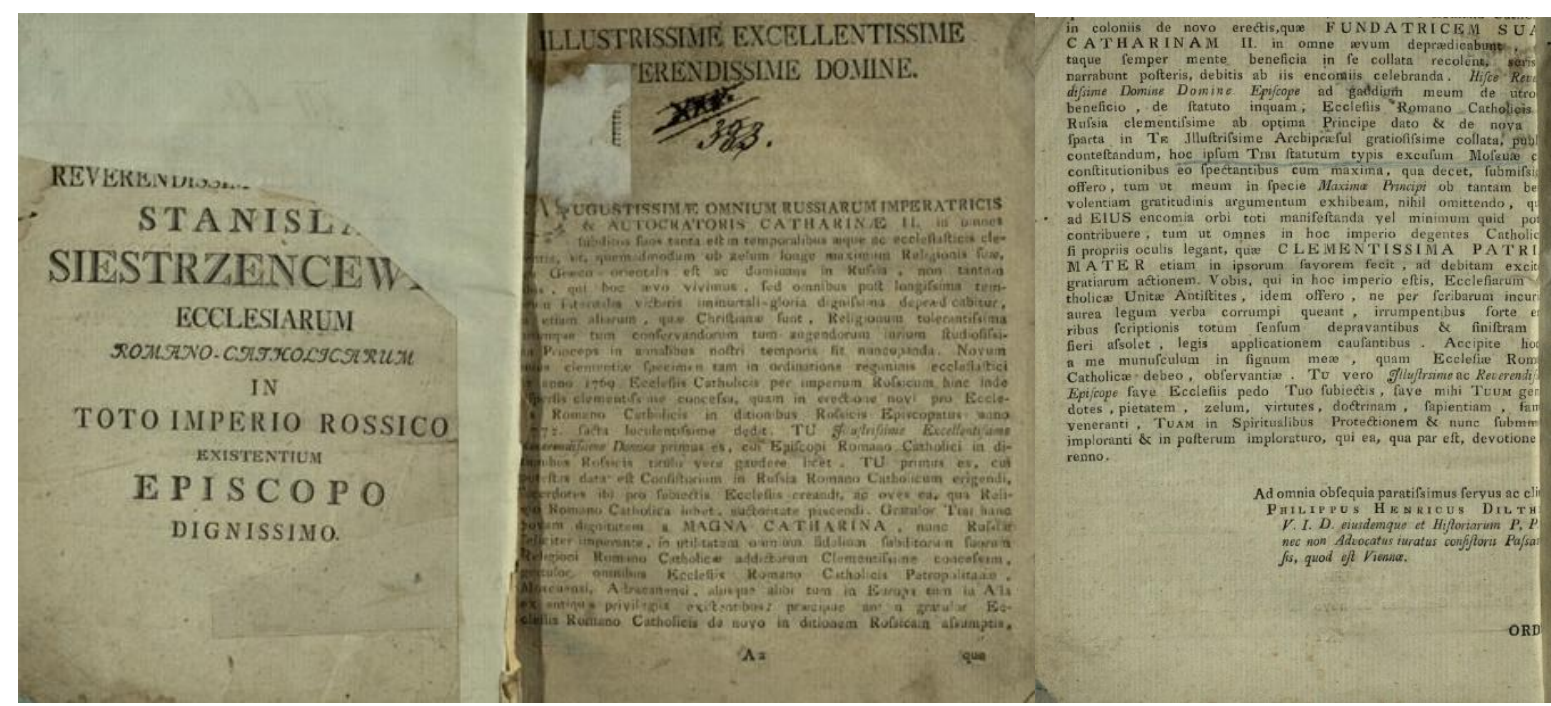

First pages of the set of bilingual documents with the dedication of Dr. Philipp Heinrich Dilthey to the Reverend Stanislav Sestrentsevich.

\footnotetext{
${ }^{17}$ The Confederation of Bar was a political-military organization of nobility and fervent Catholic elite, formed in the fortress of Bar (in southern Poland) in 1768, militarily opposed to the proposal of King Stanislav Poniatowskiy and the Russian government of political equality and civil of religious minorities (Orthodox and Protestant) with Catholics.
} 
DOCUMENT \# 4

FOUNDATION DIPLOMA OF THE CATHOLIC BISHOP IN THE RUSSIAN EMPIRE.

ON JUNE 12, 1774.

The Diploma confirms the policy of religious tolerance towards the Roman Catholic confession for residents since Peter I, which applies to all Catholics and Catholic orders, including the annexed Byelorussian Society of Jesus. The personal properties or ecclesiastical institutions to which, swearing fidelity to the Empress, acquire citizenship will be kept intact. The decision to group parts of bishoprics that remained in the added territory in a Diocese is ratified, also encompassing all the cities of the Empire where the faithful reside. Furthermore, the leadership of the Diocese by the Belarusian Bishop, Venerable Stanislav Sestrentsevich, residing in the city of Mogilev together with the Consistory, is reaffirmed. He will be in charge of solving religious affairs, according to their sacred canons, and will be in perpetual attention and observation of the maintenance of the economy of the churches and respect for the parishioners, according to the Regulation of 1769, updated for the new conditions.

\section{DOCUMENT \# 5}

COMMUNICATION OF YOUR EXCELLENCE THE GENERAL GOVERNOR OF BELARUS, THE IMPERIAL LIEUTENANT AND KNIGHT OF SEVERAL AWARDS OF HONOR COUNT Z. G. CHERNISHOV TO YOUR REVEREND EXCELLENCE THE BISHOP OF BELARUS AND GENTLEMAN STANISLAV SESTRENTSEVICH. ON OCTOBER 1, 1778.

Bishop Stanislav Sestrentsevich did not have direct access to Ekaterina II and all the information of the Diocese was given to him through the Governor-General of Belarus, who had a residence in Saint Petersburg. The Bishop found it very important to exchange the Polish pectoral crosses still worn by his Belarusian canons for the Russian insignia. The Empress by the same route authorizes him to do so. 
DOCUMENT \# 6

MANDATE NOT TO ADMIT FOREIGN VISITORS AND PRIESTS. JULY 13, 1779.

GOVERNOR GENERAL OF BELARUS Z. CHERNISHOV TO THE BELARUS BISHOP

\section{S. SESTRENTSEVICH.}

Governor Chernishov orders the Bishop to close all possible entrances to Belarus to apostolic visitors and foreign priests who arrive with attempts to intervene in the direction of the Roman Catholic Church in the territories of the domain of His Imperial Majesty, and warns him of these characters.

Thus, strong anti-Russian propaganda between Catholics and Belarusian Uniates and the access of the Holy See messengers with papal bulls is blocked.

In Belarus, there were 201 Jesuits under imperial protection. Although the Society of Jesus was abolished in July 1773, they were unable to carry out the Pontiff's decision and leave the Order without promulgation in his presence of the Brief Dominus ac Redemptor prevented by the Empress.

\section{DOCUMENT \# 7}

NOMINATION OF THE REPRESENTATIVE OF THE BISHOP OF BELARUS IN THE TRAS DVINA REGION. ON DECEMBER 19, 1780.

BY DIVINE GRACE, WE EKATERINA SECOND EMPRESS AND AUTOCRAT OF ALL RUSSIA, ETC., ETC., ETC. ${ }^{18}$ TO OUR SUPREME GENERAL AND GENERAL GOVERNOR OF BELARUS, COUNT CHERNISHOV.

The Empress responds positively to Bishop Sestrentsevich's request through General Governor Chernishov to allow him to change his representative in one of the regions of Belarus, according to the Bishop's own choice.

\section{DOCUMENT \# 8}

ORDER NOT TO ADMIT FOREIGN PRIESTS TO OUR EMPIRE WITHOUT BEING CALLED BY THE BISHOP OF BELARUS. ON JANUARY 2, 1780.

\footnotetext{
${ }^{18}$ The Empress had a long list of the titles of her sovereignty.
} 
TO OUR GENERAL GOVERNOR OF THE METROPOLITAN PREFECTURE ${ }^{19}$, THE PRIVATE COUNSELOR MR. VOLKOV.

The sovereign confirms her trust in the Bishop of Belarus for his loyalty and exact fulfilment of his mandates. It orders the General Governor of Belarus, the provincial Governors, and other authorities, to establish a careful observation of obedience to the Bishop - the legitimate pastor of all Catholics in the Empire. But not all the clergymen recognized him as such, for being chosen by the imperial will without notice and blessing from the Holy Father. In turn, the Jesuits, maintained by Ekaterina II in Belarus, sought their historic independence, causing conflicts with the Bishop. The intervention of foreign priests in spiritual matters is prohibited secretly and without the Bishop's knowledge. Those who dare must be expelled from the country by the authorities, punishing those who provide shelter and mobilization to the foreigners.

\section{DOCUMENT \# 9}

MANDATE OF YOR IMPERIAL MAJESTY AUTOCRAT OF ALL RUSSIA. ON JANUARY 1, 1782.

THE GOVERNMENT SENATE COMMUNICATES TO THE PEOPLE ON THE FOUNDATION OF THE ARCHBISHOP OF MOGILEV AND APPOINTMENT OF THE ARCHBISHOP STANISLAV SESTRENTSEVICH. ON JANUARY 26, 1782.

Recognizing the contribution of the Belarusian Bishop for his zeal for the Church and good administration of the flock entrusted to him, the sovereign confirms his monarchical favor and appoints him the Archbishop of Mogilev with residence in this city, converting the Belarusian Diocese into the Archbishopric of Mogilev, which includes the convents of the Catholic faith and all the parishes in Belarus, the Catholic communities of St. Petersburg, Moscow, and everywhere in the Russian Empire. It also orders to improve their economic support and assign the Assistant Coadjutor with generous funding. Ekaterina issued the Supreme Edict of the founding of the Archbishopric directed by Sestrentsevich, without consulting Rome, forbidding him to carry out any Roman order except those that emanate from her or the Senate. In turn, she threatened Pius VI to return the 800,000 Uniate Catholics of the Greek Orthodox rite - to Orthodoxy. That was the reason that, despite such arbitrariness, the papal nuncio, acting "reluctantly" and proceeding with the authority granted

\footnotetext{
${ }^{19}$ Saint Petersburg Prefecture.
} 
him by Pius VI in the bull "Onerosa pastoralis officii" of April 15, 1783, canonically approved the creation of the Archbishopric of Mogilev by an act of December 8, 1783. Later, Archbishop Sestrentsevich, at the request of Ekaterina II, received from the same Pope the title of apostolic legacy (1795) and the privilege of wearing the cardinal vestments.

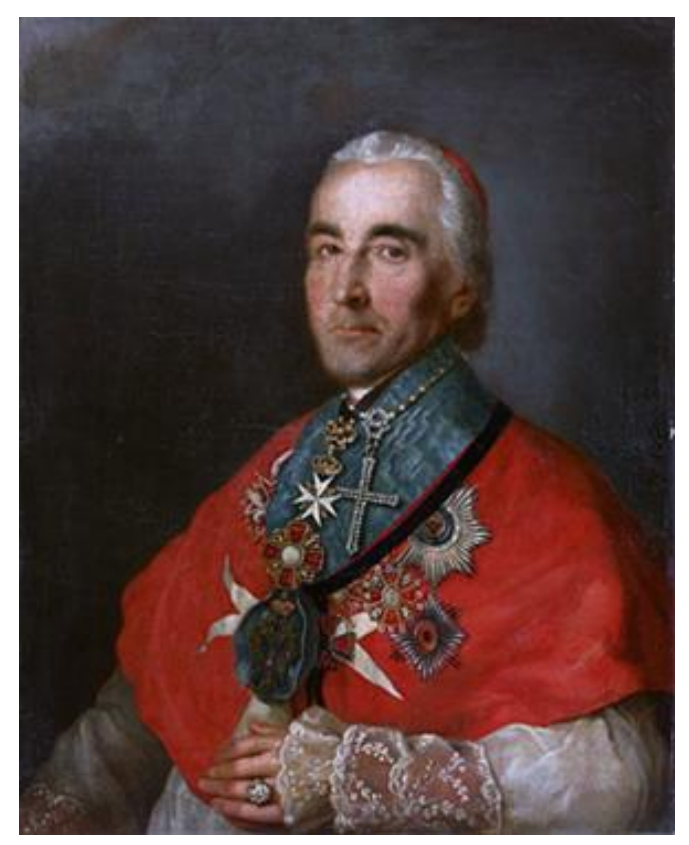

Archbishop Stanislav Sestrentsevich ${ }^{20}$

\section{DOCUMENT \# 10}

\section{MANDATE OF HER IMPERIAL MAJESTY AUTOCRAT OF ALL RUSSIA ON ELECTION OF JESUIT VICAR GENERAL. ON JUNE 25, 1782.}

\section{FROM THE GOVERNMENT SENATE TO THE ARCHBISHOP OF MOGILEV STANISLAV SESTRENCEVICH. ON JULY 24, 1782.}

The Empress, through the Senate, grants the Jesuit Community residing in the Empire, to choose from among them its Vicar General, who, following the rules of his Order, may designate the Provincials and other Superiors, informing him through the Archbishop of the name of the chosen one. The chosen one was Father Stanislav Chernevich, Superior of the Jesuits of the Major College of the city of Polotsk. Experienced politician, Chernevich leads all Jesuits of the new Russian territory to take the prescribed oath to the Sovereign. They

\footnotetext{
${ }^{20} \mathrm{https} / / /$ commons.wikimedia.org/wiki/File:Stanis\%C5\%82aw_Bohusz_Siestrze $\%$ C5\%84cewicz.PNG. Visited 07.04 .2018
} 
swore even on behalf of foreign members of the Company (from Poland). This public act of the Order made a strong impression on the Catholics, and by the new year of 1773, all clergy of Belarus was sworn in. The Russian government took the Jesuits under its protection. In this way Chernevich saved the Society of Jesus in the territory of Belarus, suppressed by Pope Clement XIV in July 1773.

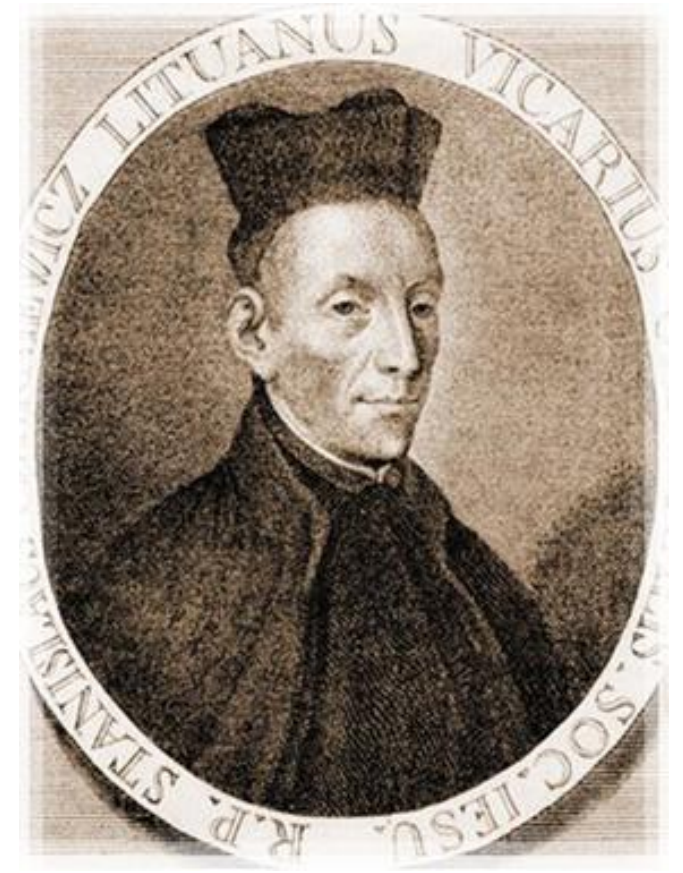

Stanislav Chernevich Vicar General of the Jesuit Community in the territory of Belarus ${ }^{21}$

\section{TRANSLATION INTO ENGLISH OF THE TEN ${ }^{22}$ DOCUMENTS OF SUPREME EDICTS OF EKATERINA II ON THE EXISTING CATHOLIC CHURCHES IN RUSSIA}

DOCUMENT \#2

ORDER TO OUR SENATE ON THE JURISDICTION OF THE CHURCHES FOR BOTH OUR ORTHODOX CONFESSION, AS WELL AS FOR ROMAN AND UNIATE GREEKROMAN CATHOLIC INSTITUTIONS IN NEW TERRITORIES OF WHITE RUSSIA ${ }^{23}$,

\footnotetext{
${ }^{21}$ Father Stanislav Chernevich, from 1759 to 1768, worked in Rome as secretary and procurator of the Polish Assistance of the Society of Jesus. In 1769 he was appointed by General Ricci as Rector of the Polotsk Major College in Belarus of the Jesuit province of Mazovia. After the partition of Poland in 1772, he was appointed by the Provincial of Mazovia, who resided in Warsaw, as Vice-Provincial of Belarus. He directed the Vice Provincial Curia of the separated Jesuits of Poland. https://psu.by/faculty/fef/242-nasledie-polotskoj-zemli/ 6644-polotskijiezuitskij-kollegium-v-1773-1812-gg Visited 23.03.2019.

${ }^{22}$ See Document \# 1 in REHJ. XXXIX (2017), pp. 385-402.

${ }^{23}$ Belarus.
} 
RECENTLY ACQUIRED FROM POLAND TO THE RUSSIAN EMPIRE. ON DECEMBER 14, 1772.

ON THE ASSIGNMENT OF THE SPIRITUAL DIRECTION OF OUR ORTHODOX FAITH IN TWO NEW PROVINCES TO THE ASSIGNED HIERARCHS; TO THE ROMAN CATHOLIC BISHOP IS GIVEN THE DIRECTION OF THE ROMAN CONVENTS AND CHURCHES, AS WELL AS IN THE ACQUIRED PROVINCES OF POLAND, AS IN ALL CITIES IN THE RUSSIAN EMPIRE, AND TO THE UNIATE ARCHBISHOP, THE MONASTERIES AND CHURCHES, ONLY IN THE NEWLY ACQUIRED PROVINCES; ABOUT THE EXISTENCE IN THEM OF SPIRITUAL CONSISTORIES; ABOUT THEIR MAINTENANCE; ABOUT COMPLAINTS, ABOUT THEIR DECISIONS AND ABOUT NON-PUBLICATION OF PAPAL BULLS AND ORDERS WITHOUT THE HIGHEST PERMISSION. ${ }^{24}$

Supreme Edict sent to the Senate on December 14, 1772

In the provinces now acquired by US from Poland to the Russian Empire, there must be a presence in them of spiritual leaders and direction of spiritual affairs, as there is for the churches of OUR Glorious Orthodox Faith, as well as for the Catholic churches and the Uniate (Greek-Roman) churches We established the following:

1. The provinces of Vitebsk, Polotsk and Dviná will be incorporated into the Pskov Eparchy ${ }^{25}$ of the Russian Greek Orthodox Creed.

2. The provinces of Mogilev, Orsha, Mstislav and Rogachev, with the churches and believers of OUR Orthodox law, should arm the Mogilev ${ }^{26}$ Eparchy until the new decree. We order that the current Orthodox Bishop of Mogilev Georgiy, who must remain be called as he is called until now. On these two points, WE have given OUR special decree to OUR Synod.

3. Although the position of Catholic Bishop is vacant for now, the Bishop will soon be assigned. To him we shall entrust all Roman Catholic convents ${ }^{27}$ and churches in the spiritual government and, in addition, the churches of Roman Catholic law, which are located in different cities of OUR Empire to this Catholic Bishop, not only because of the demands of his parishioners should order parish priests and priests, but to resolve all spiritual matters between parishioners and their Reverend Fathers, according to the faith and rites of the

\footnotetext{
${ }^{24}$ Op.cit. (n.1) pp.1006 s doc. 149.

${ }^{25}$ The Eparchy is the Diocese in Russian.

${ }^{26}$ The territorio and the number of faithful of the Orthodox Eparchy of Mogilev grew sharply.

${ }^{27}$ Ekaterina writes monasteries, because in Russia there are no convents, but monasteries.
} 
Church. In order for the churches to administer in a good way their financial affairs, the collection of the faithful, and other inputs which may arise in various circumstances, WE put the same Regulations to the Catholic Bishop, which WE have delivered to the Catholic Church of St. Petersburg on February 12, 1769, signed with OUR handwriting, in what then only remains out of the Law, what was prescribed by the circumstances of that time on the call of the Fathers of Rome ${ }^{28}$ and in the other, all the questionable points, are interpreted clearly on what to do and be.

4. The current Uniate Archbishop must stay in the same Diocese in which he is now, the convents and Uniate churches with the parishioners are entrusted to him in spiritual direction, only in all these acquired provinces. In the maintenance of the parishes, one must act by the prescription of the same Regulation of the Catholic Church of Saint Petersburg ${ }^{29}$.

5. These two Catholic hierarchs ${ }^{30}$ are to have in the bishops' houses Spiritual Councils for the administration of religious affairs, for which they may choose two or three clergymen according to their own judgment.

6. The Catholic Bishop, with all the bishop's house and the Consistory, will be supported by the Canonicates of Vilna ${ }^{31}$ - which now belong to OUR Empire -, by the ecclesiastical collections received by the parish priests and clergy from Roman Catholic rituals, and by donations in all the convents and Catholic churches, which belong to the Bishop. The Archbishop of Uniate church will have to keep the same support he has now until the corresponding decree.

7. The provincial governors of Pskov and Mogilev must look out of the corner of their eye for the bishops, canons, pastors or any other priests, regardless of their ecclesiastical level of the Catholic or Uniate Churches, not to dare in any way either openly or secretly, to convert the believers of OUR Greek confession to the other creed, of which the -General Governor by OUR order must publish a Manifesto signed by him in all the newly acquired provinces, threatening to punish for such a crime according to the Law.

8. If the Roman Catholic Bishop or the Archbishop of the Uniate Church resolved an ecclesiastical matter about the economy and good order in monasteries and parish churches, and someone was not satisfied with his decision, that person (s) may appeal to the Livonia

\footnotetext{
${ }^{28}$ Until 1772 in Russia there was no Catholic clergy.

${ }^{29}$ Set up the committee of trustees democratically elected by parishioners to manage the economy of the institution.

${ }^{30}$ The Roman Catholic Bishop and the Uniate Bishop.

${ }^{31}$ The current capital of Lithuania Vilnius.
} 
${ }^{32}$ College of Judges, and if he was not satisfied with the judges, he could appeal to the Senate, which was communicated in the Regulations in 1769 , delivered to the St. Petersburg Catholic Church .

9. As it was already communicated ${ }^{33}$, in these provinces the Catholic Church and the Uniate remain unchanged in their dogmas and rules. Should a Papal Bull or other mandate appear from the Pope directly or through the Congregation or through other foreign ${ }^{34}$ Catholic leaders sent to the Roman Catholic and Uniate leadership at any spiritual level, to communicate them to Roman Catholics and Uniate in the newly acquired lands of Poland, the said Belarusian church leaders must immediately send them ${ }^{35}$ to the General Governor- of White Russia to present them to the US and to await OUR permission to publish them among the faithful. From the above, WE have sent the respective orders signed by the US.

The original is signed by YOUR IMPERIAL MAJESTY:

EKATERINA

On December 14, 1772.

\section{DOCUMENT \#3}

MANDATE TO OUR SUPREME GENERAL AND GENERAL GOVERNOR OF BELARUS COUNT CHERNISHOV ON THE APPOINTMENT OF STANISLAV SESTRENTSEVICH AS BISHOP OF BELARUS. ON NOVEMBER 22, 1773.

By the OUR Manifesto of December 14, 1772, published in the newly acquired provinces of Poland to OUR Empire, WE had ordered to appoint Bishop Georgiy of OUR Glorious Religion for the Orthodox Eparchy of Mogilev and to leave until further term the former Uniate Archbishop of Polotsk in the previous conditions for the churches of the Uniate creed $^{36}$. But at that time, the Catholic Bishop had not yet been nominated and now, by OUR benevolent decision, we appoint in this position as Bishop of the Catholic religion Stanislav Sestrentsevich on Bishop Mallense ${ }^{37}$, who until now was Vicar and Canon of the Diocese of

\footnotetext{
${ }^{32}$ The legal institution relating to the Baltic territories acquired by Peter I in the Nordic Wars 1700-1721.

${ }^{33}$ In the First Manifesto to the people of Belarus after the Polish territorial division on August 16, 1772.

${ }^{34}$ The Polish Catholic hierarchs tried to maintain their influence in the territories lost by Poland.

${ }^{35}$ The Papal Bulls and the opinions received from abroad.

${ }^{36}$ Greco-Roman Church.

${ }^{37}$ In April 1773 Sestrentsevich Bogush was appointed by Rome as Bishop Mallense "In partibus infidelium", which means in Latin "in the infidel lands." On October 3, 1773, he was consecrated as Titular Bishop and
} 
Vilna. Consequently, we declare about him the following:

1. He must bear the title of Bishop of Belarus of all Catholic churches.

2. His place of residence will be the city of Mogilev. In the beginning, he will live in a rented house, which will be the quietest and most comfortable in this city. For the expenses of his temporary housing, we order to give him, the Belarusian Bishop, the annual income collected up to this time from the ecclesiastical and canonical institutions of this Diocese which are not yet registered or allocated for certain expenses.

3. Let a brick house be built for the Bishop of Belarus at a convenient place in the city of Mogilev.

4. All the ecclesiastical revenues of the Catholic Diocese are to be given to the provincial treasury, and in lieu thereof, 10,000 rubles $^{38}$ of the provincial revenues are to be given to the Bishop of Belarus for his own support and that of the Consistory and its members; of this sum he is to maintain himself and the bishop's house, distributing the aforesaid revenues as he sees fit.

5. He is in charge of the bishop's government in the Catholic Churches, both in the annexed provinces of Poland and in Petersburg, Moscow and other cities of OUR Empire. With regard to appeals to his episcopal justice about economic and civil lawsuits between churchmen and their parishioners, excluding problems of religion, he has to follow OUR previous Mandate where these matters have been explained and, above all, OUR Regulation for the Catholic Church of Petersburg of February 12, 1769.

6. For the foundation in OUR Empire of the Catholic Diocese, called Belorussian, and the approval in the office of the Bishop of Sestrentsevich, WE have ordered OUR Senate to prepare the corresponding Decree for OUR signature.

The original is signed in the handwriting of YOUR IMPERIAL MAJESTY:

\section{EKATERINA.}

On November 22nd, 1773. In Villa Regia ${ }^{39}$.

\footnotetext{
appointed Bishop Sufragan of the Diocese of Vilna, for the part of this Diocese that passed to Russia after the first partition of Poland.

${ }^{38}$ The salary assigned is comparable to that of a minister in your cabinet. The salary of the governor of the provincial capital Novgorod did not exceed 800 rubles, and that of the governor of St. Petersburg was 1,200 rubles.

${ }^{39}$ The Tsarskoye Selo Palace near Saint Petersburg.
} 


\section{DOCUMENT \#4}

DIPLOMA OF THE FOUNDATION OF THE CATHOLIC BISHOPRIC IN THE RUSSIAN EMPIRE. ON JUNE 12, 1774.

\section{BY THE GRACE OF GOD}

WE

\section{EKATERINA II}

The Empress and Autocrat of All Russia,

the Czarina of the lands of Moscow, of Kiev, of Vladimir, of Novgorod; the Queen of Kazan, of Astrakhan, of Siberia; the Lady of Pskov, the Grand Duchess of Smolensk, the Duchess of Estland, Lifland, Korelia, Tver, Yugorskaya, Perm, Viatica, Bulgaria, and other lands, the Grand Duchess of the land of Novgorod Nizovskiy, the lands of Chernigov, Ryazan, Rostov, Yaroslavl, Beloozero, the Sovereign Udorskaya, Obdorskaya, Kandiyskaya and all the Nordic lands, and the lands of Iveria, of Karshaline and Georgian Kings, and the lands of Kabarda, of the Cherkese Princes and of the Mountains and others the Crown Queen and Possessor.

We declare to each and everyone who should know and, above all, to the White Russian Governorate and all residents of OUR Roman Catholic Empire that as many years ago, OUR RIP ancestors have allowed all residents of the Roman Catholic Creed to confess their Religion freely and WE OURSELVES confirm it; in the capital cities of St. Petersburg and Moscow they have built, by the same parishioners, long ago the Catholic temples as in some other cities, where they do service according to the religious norms, freely and without obstacles.

Now, in OUR happy reign, WE add from Poland to OUR Empire a few provinces under the name of Belarus, with many Catholic bishoprics that entered OUR citizenship. For this reason, for the sake of tranquility and good order among the Roman Catholic clergy, WE decided that it is good not only to group all the former Catholic bishoprics into one Catholic Diocese $^{40}$ but to include in it all the Roman Catholic communities both in the capital cities and in other cities of the OUR Empire in places far away. WE have named the above mentioned Diocese as a Belarusian Catholic Diocese, directed by the Catholic Bishop whom we order to be called the Belarusian Bishop of all Catholic churches - together with

\footnotetext{
${ }^{40}$ In the original Russian written Catholic Eparchy.
} 
the Consistory, whose members are appointed according to his will; and we leave him free to follow the canonical rules, not only in founding and maintaining in good condition his Catholic convents, but also the canonical temples and parish churches, where he has the power to consecrate priests for their sacred rites and distribute additional sustenance for each parish church. Also, the Bishop of all the Roman Catholic churches ${ }^{41}$ in the territory of OUR Empire has the power to extend his faculty in solving matters of his religion, according to their sacred canons.

And as regards the good order of the economy of the Roman Catholic Churches, both in the Diocese of Belorussia and in those existing in all OUR Empire, let the Regulations given by the US and signed by OUR own hand to the Catholic Church in St. Petersburg on February 12,1769 , be immutably followed, and then confirmed by the Decree of February 12, 1772, so that in the event of a disagreement of someone in economic problems, he could appeal to OUR College of Justice of the affairs of Lifland, Estland and Finland, ${ }^{42}$ based on the aforementioned Regulations.

By OUR Supreme mandate and in the name of OUR Belarusian General Governor, an edict was published on September 5, 1772, in all Belarusian provinces, to the effect that not only WE solemnly confirm to each and everyone full freedom to exercise without limit and publicly acts of their religion, but also the legitimacy of possessions and personal property, and of all Catholic ecclesiastical Orders that have acquired OUR citizenship, as well as the future of those who have come with the desire to remain under OUR domain. All its monasteries, schools, colleges, as well as the movable and immovable goods of these monasteries, must remain intact in their integrity of ancient properties. From what has been said, every Catholic Bishop of Belarus must be in perpetual observation and attention so that OUR solemn promise remains firm and immovable eternally, while all Catholic religious Orders in the OUR Empire, including the Jesuits, firmly fulfil themselves the sworn fidelity and obedience.

Thus founded the Catholic Diocese of Belarus, WE designate as the Bishop elected by the US the Venerable Stanislav Sestrentsevich of Bogush the former Bishop of Vilna, Canonical of Vilna and Knight of the Polish order of Stanislav, whom WE designate as the place of residence the city of Mogilev. We assign for his episcopal house and for the support of the members of the Consistory an increase of the annual payment.

\footnotetext{
${ }^{41}$ In the original Russian, kirja (church) is written in lower case, Roman Catholic in capital letters.

${ }^{42}$ Present Latvia, Estonia and Finland, territories occupied by Peter the Great.
} 
In confirmation of the above for eternity, this OUR merciful Diploma is delivered to the Catholic Diocese of Belarus, signed in OUR hand, and ordered to be stamped with OUR Imperial Stamp.

The original is signed in YOUR MAJESTY'S handwriting:

EKATERINA

It has given in the Villa Regia. on May 12, 1774, in OUR twelfth year ${ }^{43}$.

DOCUMENT \#5

COMMUNIQUÉ FROM YOUR EXCELLENCE THE GENERAL GOVERNOR OF BELARUS, THE IMPERIAL LIEUTENANT AND KNIGHT OF SEVERAL AWARDS OF HONOR COUNT Z. G. CHERNISHOV TO YOUR REVEREND EXCELLENCE THE BISHOP OF BELARUS AND GENTLEMAN STANISLAV SESTRENTSEVICH. ON OCTOBER 1, 1778.

According to the notification of Your Reverend Excellency, regarding the insignia of the canons of his Diocese, which would carry pectoral crosses with black insignias, I had had the honor to humbly refer it to Your Imperial Majesty and had made myself worthy of hearing Your Most High authorization, that the pectoral crosses of the mentioned canons should be placed the Russian Imperial Eagle, instead of the Polish Eagle.

To Your Reverend Excellency the Bishop of the Catholic Church of Byelorussia Petrópoli4 ${ }^{44}$ On October 1, 1778.

DOCUMENT \#6

MANDATE NOT TO ADMIT FOREIGN VISITORS AND PRIESTS ON JULY 13, 1799.

FROM THE GENERAL GOVERNOR- OF BELARUS Z. CHERNISHOV TO THE BELARUSIAN BISHOP S. SESTRENTSEVICH.

Since the arbitrary arrivals of foreign priests of the Catholic confession in the Governorate of Belarus under the name of provincials, apostolic visitors etc., especially their intervention in

\footnotetext{
${ }^{43}$ Respecting the way of putting the dates of the document.

${ }^{44}$ One way to mention St. Petersburg.
} 
the direction in the Roman Catholic Church, the moving of the Purposes ${ }^{45}$ and the movement of the religious from place to place without their authorization, do not correspond to the Highest decrees. Your Imperial Majesty clemently communicates that such arrived by his judgment ${ }^{46}$ and with attempts to intervene in the direction of the Roman Catholic Church, in the territories of the domain of Your Imperial Majesty, will not be tolerated in any way, and that said government will remain in the hands of His Excellency, so that it by the Highest will of Your Imperial Majesty, is entrusted to You.

Therefore, I ordered the Provincial Governors of Byelorussia, that all priests coming to the border be interrogated about the reason for their arrival, and those who come ${ }^{47}$ to visit and supervise the convents without their authorization, not to let them enter the interior of the government of Byelorussia. Those, who present their personal needs to communicate with You, should be accompanied from the border to Your Reverence as soon as they arrive, for due to the Highest decree of YOUR IMPERIAL MAJESTY, do not let Your Reverence inform me so much of their arrival as if they will be received in Your Diocese and used for Your service; or being unnecessary, be sent back abroad; meanwhile, their conduct should be monitored, because You will respond directly since You are the only shepherd entrusted with it.

With deep respect to Your Most Reverend Excellency, Your humble servant

Z. Chernishov.

In Yaropolcha ${ }^{48}$. On July 13, 1779.

\section{DOCUMENT \#7}

THE NOMINATION OF THE REPRESENTATIVE OF THE BISHOP OF BELARUS IN THE REGION AFTER DVINÁ. ON DECEMBER 19, 1780.

BY DIVINE GRACE, WE EKATERINA II, EMPRESS AND AUTOCRAT OF ALL RUSSIA, ETC. TO OUR Supreme General and General Governor of Belarus, Count Chernishov.

\footnotetext{
${ }^{45}$ The Superiors.

${ }^{46}$ Without permission.

${ }^{47}$ The apostolic visitors sent from Rome.

${ }^{48}$ The property of the General Governor located near Saint Petersburg.
} 
We benevolently grant the request of the Bishop of Belarus of the Roman Church Stanislav Sestrencevich to put as his representative in the region After Dviná the Superior of the Churches of this area Canon of the Catholic faith Georgiy Pavlovsky, instead of the Prelate Sosnovsky who occupied this position.

Always favourable with OUR Imperial benevolence.

Signed in the handwriting of YOUR IMPERIAL MAJESTY

EKATERINA

St. Petersburg. On December 19, 1780.

\section{DOCUMENT \#8}

ORDER NOT TO ADMIT FOREIGN PRIESTS TO OUR EMPIRE WITHOUT BEING CALLED BY THE BISHOP OF BELARUS. ON JANUARY 2ND, 1780.

TO OUR GENERAL GOVERNOR OF THE PETROPOLITAN ${ }^{49}$ PREFECTURE, THE PRIVATE COUNSELLOR MR VOLKOV.

Being free to exercise the Roman Catholic religion in OUR Empire under Our protection, the high ecclesiastical power was handed over by OUR Mandate to the Bishop of Belarus, Stanislav Sestrentsevich, who is with OUR benevolence. In order that this benevolence may be exactly fulfilled everywhere, WE order that on behalf of OUR General Governor of Belarus, OUR Prefects and other authorities, careful observation will be established in compliance:

first, that the clergy of all Roman convents and churches, existing in Russia will render due obedience to him (Bishop);

secondly, that no Roman ecclesiastic dares to perform spiritual functions, pastoral visits and other offices of that rite outside the above mentioned, which only have the authorization of the mentioned Bishop - who by OUR will is constituted in OUR Empire as the legitimate pastor of the Roman Church -, have licenses and blessings that can be presented in writing. For, when any of these scriptural holders by reason of death or otherwise leaves his office, the Bishop of Byelorussia must be informed; but if any of the clergymen should be found to intervene without the Bishop's knowledge, in spiritual matters of the Roman Church and in

\footnotetext{
${ }^{49}$ Saint Petersburg Prefecture.
} 
the offices of faith, they must be taken from one district to another, from one prefecture to another, to the borders of the Empire, and driven out of it. Those acts should be reported to the US. We confirm, furthermore, that none of those clergies will be admitted to OUR territory unless they present the testimony of their convocation or the permission of the Bishop of Belarus. In the event that they declare a real need to communicate with him, such should be forwarded to OUR General Governor of Belarus, and in his absence, to the Provincial Governor of Mogilev, who may send them to the Bishop.

The original is signed by YOUR IMPERIAL MAJESTY:

EKATERINA.

In St. Petersburg. On January 2, 1780.

\section{DOCUMENT \#9}

SUPREME MANDATE OF YOUR IMPERIAL AUTOCRATIC MAJESTY OF ALL RUSSIA. ON JANUARY 1, 1782

THE GOVERNMENT SENATE COMMUNICATES TO THE PEOPLE ABOUT FOUNDATION OF MOGILEV ARCHBISHOPRIC AND APPOINTMENT OF ARCHBISHOP STANISLAV SESTRENTSEVICH

In the Supreme Mandate of Your Imperial Majesty, signed in your handwriting and sent to the Senate on January 1, 1782, it is written:

"Bearing in mind that for OUR ancestors and for US the Roman Church has the freedom to profess and possesses a considerable number of those who practice the Roman Catholic doctrine in various places and on the most remote borders of Russia, in 1775 we realized that it is necessary to define for OUR subjects the Bishop, so we have chosen the service of Bishop Stanislav Sestrentsevich, to whom we owe true loyalty; and his enthusiasm for the Church, the good administration of the flock entrusted to him, and an unconditional zeal for the common good, he has won OUR monarchical favour. Now extends OUR attention from OUR loyal subjects of the Roman confession, after learning the proper information about the best management of the Church's affairs, it is deemed best to impose the following orders: 
First. In the city of Mogilev of the province of Mogilev, let there now be ordained the Archbishopric of Roman worship, including in the Diocese of the Archbishopric all parishes and convents of the Catholic faith, both in the provinces of Mogilev and Polotsk, and in both OUR capitals ${ }^{50}$ and in all places of the Russian Empire.

Second. WE assign OUR Bishop Stanislav Sestrentsevich Archbishop of Mogilev of the Roman Church.

Third. Assign a Coadjutor to help him. We appoint to this position Father Superior Joan Benislavski, Canonical of the Archbishopric of Mogilev, Abbot of Dineburg. We have indicated to take the necessary steps for his ordination as Bishop.

Fourth. Assign the annual salary to the Coadjutor of the Archbishop of Mogilev of the Roman Church about one thousand two hundred rubles ${ }^{51}$.

Fifth. The Archbishop of Mogilev of the Roman Church should not receive decrees and mandates from anyone except from US and OUR Senate.

Sixth. For the review and resolution of cases involving the use of ecclesiastical and civil law, this Archbishop in the case of trials of ecclesiastical matters is to establish a consistorial commission under his direction, composed of canons born in OUR domain or who have received OUR citizenship. For a situation where a civilian is sentenced to a penalty, the presence of a deputy in the session of the Consistory must be demanded from the civil authorities. Those who are dissatisfied with the judgment of the Consistory and the Archbishop may send their claims to OUR Senate.

Seventh. The Colleges of Justice of Lifland, Estonia and Finland are forbidden to interfere in the affairs of the Roman Church.

Eighth. The assignment of the abbots and superiors of convents, parish priests and other ecclesiastics of the Roman Church throughout the Russian Empire, is in the power of the Archbishop appointed by US. We order him to review (with the help of his assistantcoadjutor) the list of all these ecclesiastics mentioned and to leave those who were only born in Our citizenship or who have received it; to dismiss from his service those who have temporarily arrived from abroad ${ }^{52}$ and, from now on, not to accept them, strictly forbidding

\footnotetext{
${ }^{50}$ Saint Petersburg and Moscow.

${ }^{51}$ It is comparable to the salary of high government officials.

${ }^{52}$ In this way, Ekaterina closes Russia to the ecclesiastics sent from outside in order to intervene in the affairs of the Catholic Church led by Sestrentsevich, who was called in Rome by the Russian Pope.
} 
their reception under threat of civil punishment for a crime of not obeying the orders of the Superior Power.

Ninth. According to the rules of the Roman Church in St. Petersburg, confirmed in OUR Privilege and Regulation in 1769, as regards the election of trustees, the direction of income, etc., it is ordered to act according to the mentioned Privilege and Regulation; and as regards the assignment of priests, this parish is not excluded from the current rules, because the summons and acceptance of foreign monks ${ }^{53}$ for service in this parish, previously was tolerated by the non-existence in Russia of its own Bishop of the Roman faith.

Tenth. Let us confirm to OUR prohibitions declared in OUR decrees promulgated on July 3, 1779 to the General Governor of Belarus and on January 9, 1780 to all mentioned Provincial Governors $^{54}$, the Non-entry into OUR territory of foreign clergy and order, if such (foreign clergymen) should appear, wherever they may be detained and sent in custody to the corresponding governorate to be submitted to legal justice. Likewise, with those who, in contravention of this decree and without an archbishop's license, take in the above mentioned, these (accomplices) must be sent to the competent court to impose penalties according to the judicial norms in force.

Eleventh. We confirm that all the religious Orders of the Roman Rite, depending only on the Archbishop of Mogilev, his Coadjutor and his Consistory, do not dare to submit themselves to the subordination of any ecclesiastical power existing outside OUR Empire; to transfer rent or part of the rent or to have with it (ecclesiastical power) any communication, under penalty of secular judgment for the crime of not fulfilling the mandates of the Supreme Power.

We order the Archbishop of Mogilev to send US a detailed report of all the convents of his Church with an indication of which of them directly put their activity to the actions of charity pleasing to God and useful for the society, understanding by this the instruction of the youth, the service to the invalids, the sick and the forsaken and to all those in need of help. These institutions must be preserved. It should also be communicated which of them lead an idle, solitary life without any help to the neighbor, living at the public expense, so that WE (in the glory of God) could establish it in the best possible way.

\footnotetext{
${ }^{53}$ The Capuchin Fathers.
} 
Twelfth. We confirm OUR previous edicts not to receive Papal Bulls, nor messages written in his name. We order and send them to OUR Senate, which, in discussing their content, with special care in case there is something there which is properly contrary to the secular norms of the All-Russian Empire and to those of the Absolute Power given by God to US, will have the obligation to expound its opinion to us and then to await OUR license or prohibition to publish those bulls or Papal messages. We order to communicate this OUR mandate to the people, wherever it corresponds, especially in to the Roman Church. There the clergy must expose it for public knowledge."

Through the above, communicate.

Signed at the Government Senate.

Printed in St. Petersburg at the Senate Press. On January 26, 1782

\section{DOCUMENT \#10}

MANDATE OF YOUR IMPERIAL AUTOCRATIC MAJESTY OF ALL RUSSIA ON JESUIT VICAR GENERAL ELECTION. ON JULY 25, 1782.

OF THE GOVERNMENTAL SENATE TO THE ARCHBISHOP OF MOGILEV STANISLAV SESTRENCEVICH. ON JULY 24, 1782.

In the Supreme Decree of YOUR IMPERIAL MAJESTY issued on June 25, 1782, it is written as follows

"...WE benevolently grant to the Jesuit Community residing in the OUR Empire, to choose from among them their Vicar General, who, fulfilling the rules of his Order, may appoint the Provincials and other Superiors. Through the Archbishop of the Roman Church of Mogilev, they will have to communicate the name that has been elected Vicar General to OUR Senate, and this, in turn, will have to inform US. We reiterate that this Order is obliged to the obedience corresponding to its true pastor, Archbishop of the Catholic Church of Mogilev. The said Archbishop will have to watch over the rules of the said Order, which will be preserved in their integrity without any minor alteration since they are not opposed to OUR secular Laws".

The Governmental Senate (notifies You) that it ordered to communicate to the General Governor of Belarus, Senator and Knight and to the Prefects of its provinces of Mogilev and Polotsk, the Supreme Benevolence of YOUR IMPERIAL MAJESTY, and we also indicate to 
You Mr. Archbishop, to announce to the said Jesuit community this Supreme Mandate and that the appropriate persons will be responsible for its corresponding fulfillment, which will be advised by the respective authorities according to the decrees issued to them on July 24, 1782.

Through the above, contact us.

Signed at the Government Senate.

Printed in St. Petersburg at the Senate Print Shop. On July 26, 1782.

\section{BIBLIOGRAPHY ON THE RELIGIOUS POLICY OF EKATERINA II OF RUSSIA ACCORDING TO THE THEMES OF THE SET OF DOCUMENTS PRESENTED}

[1] CHISTYAKOV, O.I., NOVITSKAYA, T. E. Legislación de Ekaterina II, (Moscú, Ed. Literatura Jurídica, 2000).

[2] MADARIAGA, I., Rusia in the Age of Catherine the Great, (London,1989).

[3] BULAVINA M.A., Situación legal de la Iglesia católica en el siglo XVIII, (Stávropol, Universidad estatal, Tesis $\mathrm{PhD}$ en Derecho, 2008).

[4] GAGARIN, I.S. SJ. ¿Se convertirá Rusia al catolicismo? (Paris, San Petersburgo, 1856).

[5] PIERLING, P. SJ. La Russie et le Saint-Siege. (Paris, Vol.5.1912)

[6] TOLSTOY, D.A. Catolicismo romano en Rusia, (San Petersburgo, T.1-2, 1876)

[7] VON TANNENBERG, J. FREIHERRN Leben Katharina II, Kaiserin und Selbstherrscher aller Reußen etc., etc. (Leipzig, 1797).

[8] WINTER, E. Russland und das Papsttum. (Berlin, T.1-2.1960-1961).

[9] INGLOT, M. SI. La compagnia de Gesu nell imperio russo (1722-1820) e la sua parte nella restaurazione generale della Compagnia, (Roma, Pontificia Universita Gregoriana, 1997).

[10] LUSHPAY, V.B. Los jesuitas en Rusia en la segunda parte del siglo XIII, (Moscú, Universidad estatal de humanidades, Tesis doctoral, 2002).

[11] LUTTEROTH, H. La Russie et les jesuites de 1772 a 1820, (Paris, 1845).

[12] BLINOVA, T.B. Jesuitas en Bielorussia (Minsk, 1990).

[13] SANS I. Ma , SI. Muerte y Resurrección de la Compañía de Jesús 1773-1814, (Alicante : Biblioteca Virtual Miguel de Cervantes, 2010). 
[14] MOROSHKIN, M.YA., Jesuitas en Rusia desde el reinado de Ekaterina II hasta nuestro tiempo, (San Petersburgo, 1867

[15] Merkwürdige Nachrichten von den Jesuiten in Weißrussen. In Briefen. Aus dem Italienishen. Zwente Auflage (Frankfurt und Leipzig, 1786).

[16] MARASH, YA.N. Vaticano y la Iglesia católica en Bielorussia, 1569-1795.(Minsk, 1971).

[17] ZATKO, J. J. The organisation of the Catholic Church in Russia, 1772-1784. (London, 1965) The Slavonic and East European Review. Vol. XLIII, \#101.P.303-313.

[18] POPOV, A. N. Ekaterina II y los jesuitas. (Vestnik Evropy, 1869).

[19] ZALESSKI, S. Jezuici w Polsce.(Krakow, 1908). 